\title{
Organic matter affects fiddler crab distribution? Results from field and laboratorial trials
}

\author{
Fernando Rafael De Grande ${ }^{a}$, Priscila Granado ${ }^{a}$, Fábio Henrique Carretero Sanches ${ }^{b}$, \\ Tânia Marcia Costa ${ }^{\mathrm{c}, \text {, }}$ \\ a Postgraduate Program in Biological Sciences (Zoology), Botucatu Biosciences Institute, São Paulo State University - UNESP, 18618-000, Botucatu, SP, Brazil \\ ${ }^{\mathrm{b}}$ Center of Natural and Human Sciences, Federal University of ABC (CCNH/UFABC), 09210-170, Santo André, SP, Brazil \\ ${ }^{c}$ Biosciences Institute, São Paulo State University (UNESP), Coastal Campus, 11330-900, São Vicente, SP, Brazil
}

\section{A R T I C L E I N F O}

\section{Keywords:}

Preference behavior

Primary consumer

Mangrove macroinvertebrates

Leptuca uruguayensis

Leptuca thayeri

\begin{abstract}
A B S T R A C T
Fiddler crabs are a key benthic macrofauna group in estuarine environments. Species distribution is determined by relatively distinct zones, based on biotic and abiotic factors. As sediment organic matter is thought to be one of the most important zoning factors of mangrove macrofauna, we tested the effects of organic matter content on the intra-specific distribution of the fiddler crabs Leptuca thayeri and Leptuca uruguayensis. Organic matter content and crab abundance and size were assessed in both species by field observations, while the choice of adult or juvenile L. uruguayensis for high -or low- organic matter was tested in the laboratory. Both species showed no relationship between organic matter and crab abundance or size. Furthermore, L. uruguayensis juveniles or adults did not show any preference for specific organic matter content. Therefore, fiddler crabs intraspecific distribution in mangrove forests is not dependent of the water-land gradient decrease of organic matter.
\end{abstract}

\section{Introduction}

How species distribution is affected by abiotic and biotic factors is a central concern in ecology, and studies on intertidal ecosystems, where organism zonation is markedly visible, have been important to increase the knowledge on this topic. Mangrove crabs, for example, may have their distribution boundaries influenced by competition for space (Cannicci et al., 2018), presence of vegetation (Nobbs, 2003), temperature (Nobbs and Blamires, 2015), and other factors (Ens et al., 1993; Daleo et al., 2003; Ribeiro et al., 2005; Checon and Costa, 2017). One of the most conspicuous benthic macrofaunal groups in tropical and subtropical estuarine environments, both in abundance and biomass, are fiddler crabs (Teal, 1962; Cammen et al., 1980; Macintosh et al., 2002; Koch et al., 2005). Several species naturally coexist in intertidal areas where they can share the same resources, including food and space (Crane, 1975; Checon and Costa, 2017). Their distribution may be regulated by macroscale factors, such as latitude (Crane, 1975; Sanford et al., 2006), and microscale factors, such as species zonation across the intertidal zone (Costa and NegreirosFransozo, 2001; Johnson, 2003; Nobbs, 2003; Ribeiro et al., 2005; Martins and Masunari, 2013).

Fiddler crabs are important to the intertidal trophic chain because they alter the amount of resources available to other organisms (Kristensen, 2008). Their effect on the trophic chain can be direct, through consumption of resources when feeding, and indirect, via bioturbation of sediment when digging burrows (Botto and Iribarne, 2000; Kristensen, 2008; Michaels and Zieman, 2013; Natalio et al., 2017). Furthermore, they can be predated by fish (Krumme et al., 2007), other crabs (Daleo et al., 2003), birds (Koga et al., 2001, 2015), and mammals (Rulison et al., 2012). They are therefore an important connector for the flow of energy and nutrients from the intertidal zone to aquatic and terrestrial environments (Teal, 1962).

Fiddler crab distribution may be governed by biotic factors like dispersion, larval settlement, predation and vegetation (Epifanio et al., 1988; Daleo et al., 2003; Nobbs, 2003; Thurman et al., 2013); and abiotic factors like temperature, tidal regime, salinity, sediment grain size and organic matter quantity (Teal, 1958; Icely and Jones, 1978; Genoni, 1985; Reinsel and Rittschof, 1995; Ribeiro et al., 2005; Sanford et al., 2006; Thurman et al., 2013; Mokhtari et al., 2015). The last two abiotic factors are particularly important, since fiddler crabs have specialized maxillipeds for mechanical separation of organic particles from sediment grains (Miller, 1961; Costa and Negreiros-Fransozo, 2001; Colpo and Negreiros-Fransozo, 2013). In this sense, sediment organic matter is considered the food source for fiddler crabs and it is

\footnotetext{
* Corresponding author. Biosciences Institute, São Paulo State University (UNESP), Coastal Campus, Praça Infante Dom Henrique, S/N, Parque Bitarú, 11330-900, São Vicente, SP, Brazil.

E-mail addresses: frdegrande@gmail.com (F.R. De Grande), tania.costa@unesp.br (T.M. Costa).
} 


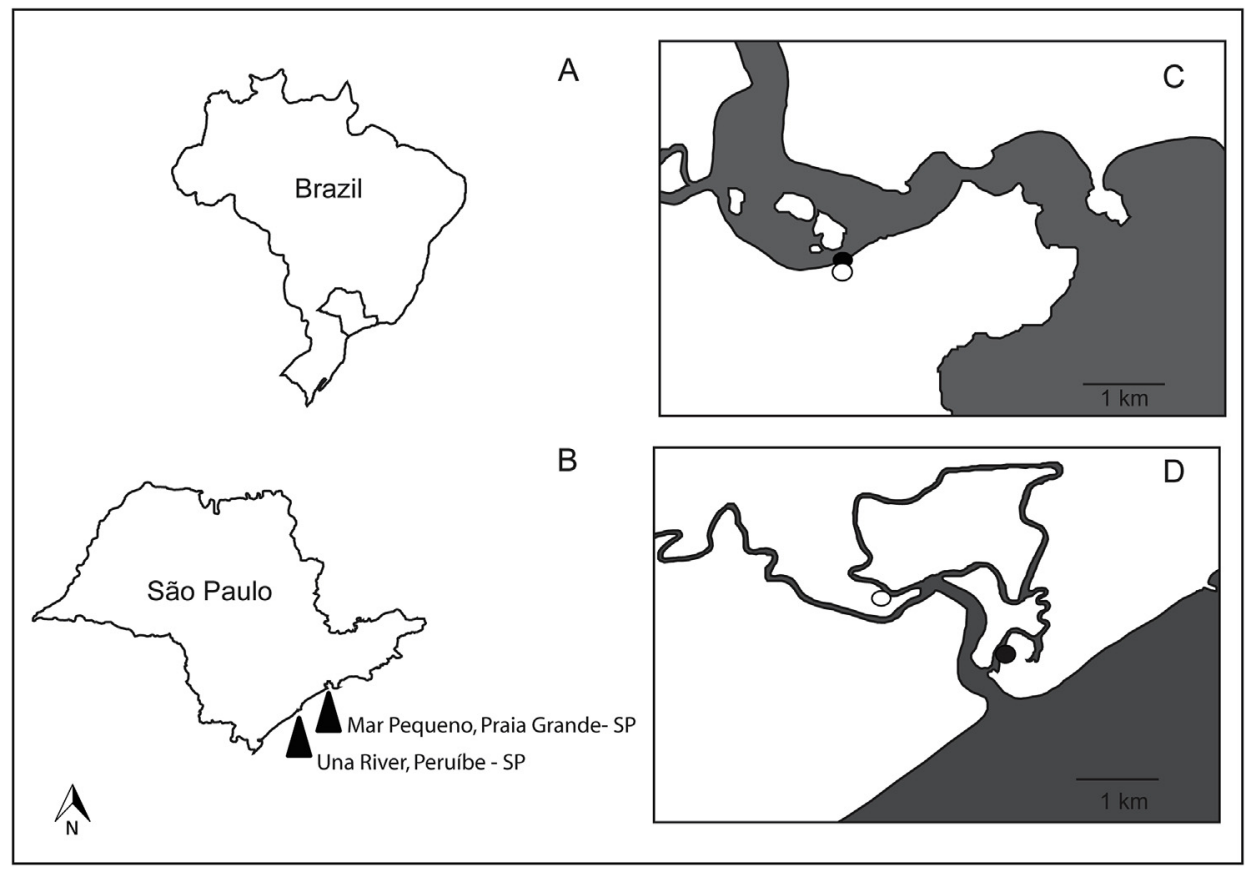

Fig. 1. The study areas. A: shows the São Paulo State at Atlantic coast of Brazil. B: shows the São Paulo coast, Mar Pequeno estuary in Praia Grande and Una River estuary in Peruíbe. C and D: represent, respectively, the Mar Pequeno and Peruíbe estuaries. The white circles in C and D represent the position of the populations studied for Leptuca uruguayensis and the black circles represent the populations of $L$. thayeri. suggested as an important factor in determining their distribution (Crane, 1975; Icely and Jones, 1978; Reinsel and Rittschof, 1995). The sediment organic matter mainly consists of leaf litter and tree fragments and may be the carbon sources for some species of primary mangrove consumers (Guest et al., 2006; Kon et al., 2007).

In the intertidal zone, sediment organic matter shows a gradient of distribution that decreases from water to land (Huettel et al., 1996; Lallier-verges et al., 1998; Bouillon et al., 2003). This gradient of organic matter is proposed to be the cause of the zonation distribution pattern of mangrove fiddler crabs (see: Icely and Jones, 1978; Koch et al., 2005; Bezerra et al., 2006; Mokhtari et al., 2015). It is known that some species may co-occur in the same estuary in relatively well distinct patches (Crane, 1975; Bezerra et al., 2006; Costa e NegreirosFransozo, 2001; Booksmythe et al., 2010; Mokhtari et al., 2015; Checon and Costa, 2017). When the relationship between species abundance and sediment organic matter is analyzed across all intertidal zone from mangrove forests, some species seem to be more dependent on organic matter than others (Costa and Negreiros-Fransozo, 2001; Bezerra et al., 2006; Thurman et al., 2013). For example, while Leptuca thayeri show a positive relationship with organic matter in the infralittoral zone, Leptuca uruguayensis show a negative relationship in the supralittoral zone (see Costa and Negreiros-Fransozo, 2001). On the other hand, when analyzed in a monospecific patch, $L$. uruguayensis show a positive relationship between abundance and sediment organic matter (Ribeiro et al., 2005). In addition, sediment organic matter has a greater influence on abundance of $L$. uruguayensis adults than on juveniles, when analyzed in the same patch (Ribeiro et al., 2005). Since crab dependence on organic matter presents some uncertainties, the relationship analysis between organic matter and population structure characteristics (such as abundance or size) could be more straightforward when considered within a single patch. This approach should be more useful to the understanding of fiddler crab distribution at a microscale because the association between variables can be more accurate.

Although association tests point to a relationship between organic matter and distribution of crabs in the field, it is not possible to state that organic matter is necessarily a cause of this (Underwood, 1997; Zar, 2010). Other factors intrinsically linked to organic matter, such as sediment grain size, which also vary within the water to land gradient, could delimit fiddler crab distribution (Costa and Negreiros-Fransozo, 2001; Yang et al., 2008; Mokhtari et al., 2015). Therefore, controlling other variables and carrying out laboratorial experiments is required to determine whether organic matter causes differential distribution of fiddler crabs.

In this work we aim to assess whether organic matter influences the intraspecific distribution of fiddler crabs. We evaluated the association between organic matter and abundance or body size of two fiddler crab species in the field: $L$. thayeri and $L$. uruguayensis. Both species were selected because they are key species in the estuaries of South America due to their abundance (Costa and Negreiros-Fransozo, 2003; Masunari, 2006), bioturbation potential (Natalio et al., 2017) and because previous studies showed that their distribution is associated with sediment organic matter (Costa and Negreiros-Fransozo, 2001; Ribeiro et al., 2005). Since the effect of organic matter on the abundance of juvenile and adult $L$. uruguayensis can be different (Ribeiro et al., 2005), we used this species as a model to test in the laboratory the hypothesis that fiddler crabs regardless of their size classes choose sediments with high amounts of organic matter to feed or inhabit. Choice tests were made in order to test whether organic matter causes variation of the intraspecific distribution of these fiddler crabs.

\section{Methods}

\subsection{Study area}

The field experiment was conducted in two different estuaries in the state of São Paulo, Brazil: Mar Pequeno, in Praia Grande, $23^{\circ} 59^{\prime} \mathrm{S}$ $46^{\circ} 24^{\prime} \mathrm{W}$ and Una River, in Peruíbe, $24^{\circ} 26^{\prime} \mathrm{S}-47^{\circ} 04^{\prime} \mathrm{W}$ (Fig. $1 \mathrm{~A}$ and B). Both estuaries were associated with mangrove forests under semidiurnal tide systems and subtropical climate without dry season (Alvares et al., 2014). In the Praia Grande estuary, Leptuca thayeri and Leptuca uruguayensis populations occur in nearby areas, but the first inhabits the infralittoral zone and the second, the supralittoral zone (Fig. 1C). Although distribution boundaries of both species overlap at some points, we studied each population separately. In the Peruíbe estuary, the $L$. thayeri population was located near the mouth of the river while $L$. uruguayensis was located at the head of the river (approximately $2.8 \mathrm{~km}$ away from each other; Fig. $1 \mathrm{D}$ ). We studied two sites per species to assess whether organic matter is associated with fiddler crab abundance or size variation independently of their location. In all populations other fiddler crab species were present but those were 


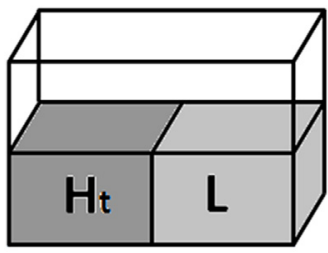

T1

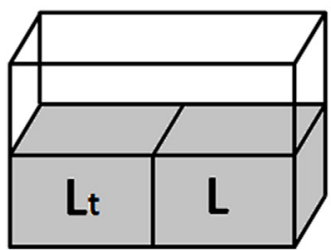

T3

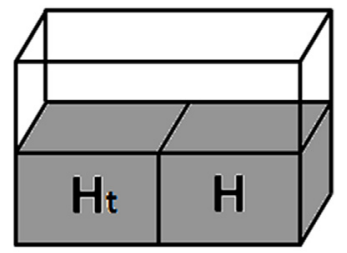

T2

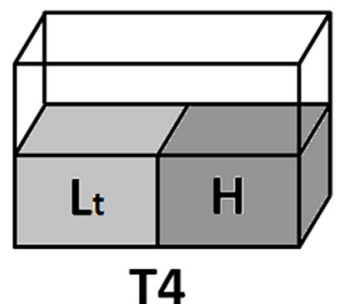

Fig. 2. Experimental design overview. Treatments (1-4) used in the experiments to determine Leptuca uruguayensis choice for sediment organic matter, in both adult and juvenile crabs. Dark gray color and $H$ indicate high organic content, light gray and $L$ represent low organic content, and $t$ indicates the reference compartment in which the proportion of total number of crab scoop, pellets and burrows was estimated.

not considered in this study.

For the laboratory experiment, crabs and sediment were collected from the Mar Pequeno estuary in Praia Grande.

\subsection{Field experiment}

To assess the association between organic matter and abundance or body size in $L$. thayeri and $L$. uruguayensis, field observations were made. Since sediment organic content decreases in a water to land gradient (Huettel et al., 1996; Lallier-verges et al., 1998; Bouillon et al., 2003), we made fifteen transects perpendicular to the water line for each population during the warm season from September 2014 to February 2015, when fiddler crabs are most active. A $75 \mathrm{~cm}$-side quadrat (experimental unit) was placed every $100 \mathrm{~cm}$ along each transect where we sampled crabs and sediment. The criterion used to start or end transects was the presence or absence of the interest-species. Therefore, transects presented different sizes depending on the sampled population (the shortest transect for $L$. thayeri was 14 and $6 \mathrm{~m}$ long, and the longest was 21 and $13 \mathrm{~m}$ long in Praia Grande and Peruíbe, respectively; the shortest transect for L. uruguayensis was 6 and $6 \mathrm{~m}$ long, and the longest was 12 and $14 \mathrm{~m}$ long in Praia Grande and Peruíbe, respectively). This assured the evaluation of organic sediment content effect only within population boundaries. In addition, transect sampling was useful to sample populations homogeneously following the downward gradient of organic matter from water towards land.

Within each quadrat 5 sediment samples of $5 \mathrm{~mm}$ depth were collected with a $3.2 \mathrm{~mm}$ diameter core. Sediment samples were pooled with the purpose of estimating mean organic content of each experimental unit ( $L$. thayeri: Praia Grande, $\mathrm{n}=177$; Peruíbe, $\mathrm{n}=117$. $L$. uruguayensis: Praia Grande, $\mathrm{n}=93$; Peruíbe, $\mathrm{n}=136)$. We only collected surface sediment because we assumed surface organic content reflected food accessed by crabs. Sediment samples were placed into labeled plastic bags and frozen. In the laboratory, samples were dried at $72{ }^{\circ} \mathrm{C}$ for $48 \mathrm{~h}$, weighted about $10 \mathrm{~g}$, incinerated at $550{ }^{\circ} \mathrm{C}$ for $5 \mathrm{~h}$ and reweighted (adapted from Luczak et al., 1997). Organic matter percentage was obtained by subtracting incinerated material weight from dry sample weight.

Each burrow within the quadrat was excavated and all crabs were collected, identified, and measured (maximum carapace width in mm). Abundance and mean size of each sex was quantified per species and quadrat (experimental unit). Crabs were released into their habitat after measurements.

\subsection{Laboratory experiment}

To test fiddler crab choice for sediment with either high or low organic content we used two size classes of $L$. uruguayensis males. In the state of São Paulo, L. uruguayensis reach sexual maturity at about $7 \mathrm{~mm}$ of carapace width (Hirose et al., 2012). Thus, we evaluated two crab sizes based on mean \pm standard deviation of carapace width $(\mathrm{t}=-18.15$, df $=78, \mathrm{p}<0.0001)$ : adults $(10.49 \pm 1.17 \mathrm{~mm})$ and juveniles $(5.99 \pm 1.06 \mathrm{~mm})$. We only used males to standardize response variables (number of scoops, pellets and burrows) once we knew such activity differed between sexes due enlarged claw present only in males (for example: females scooping twice faster than males and, consequently, producing more pellets; see Weissburg, 1992 and Weis and Weis, 2004). Furthermore we do not have any hypothesis for differences between sexes because we assumed that males and females show the same pattern of distribution since we did not observe variation of sexual proportion across the population in our field experiment (see supplementary material). We selected this species and these size classes because the relationship between organic matter and abundance is greater in adults than juveniles (Ribeiro et al., 2005) and therefore it is rational to assume that age could affect sediment choice. In addition, L. uruguayensis demand little space and sediment due to their small size.

Fiddler crabs choice was evaluated in both adults and juveniles, but not between size classes. Preference of large and small L. uruguayensis for sediment with differing organic content was tested using an experimental design consisting of three treatments, one with high organic content sediment only, one with low organic content sediment only and one with both sediments, with high and low organic content. This experimental design (Fig. 2, number of replicates per treatment $=12$ ) was based on the work of Olabarria et al. (2002) and Underwood et al. (2004). Our response variables were proportion of scoops, pellets and burrows from the fiddler crabs.

To obtain different organic contents, we used $100 \mathrm{~L}$ of superficial sediment ( $5 \mathrm{~cm}$ deep) from the $L$. uruguayensis territory. Sediment was homogenized and 10 samples were separated for organic matter quantification as described in item 2.2. Subsequently, sediment was sieved in a $0.05 \mathrm{~mm}$ mesh to remove organic fragments and 10 new samples were produced to obtain organic matter. With this procedure we removed $8.76 \pm 2.68 \%$ (mean \pm standard deviation) of initial organic matter resulting in sediment with organic content of $4.36 \pm 0.56 \%$ (mean \pm standard deviation). Ten samples of organic material retained in the sieve were analyzed under stereomicroscopy to identify their composition. Organic material was composed of $96.8 \%$ plant fragments (leaves: 55.59\%; roots: $35.87 \%$; wood: $5.34 \%$ ). To obtain sediment with a low amount of organic matter we added $2 \mathrm{~L}$ of the material retained in the sieve (tree debris) into $50 \mathrm{~L}$ of sifted sediment; to obtain high organic matter, we added $20 \mathrm{~L}$ of retained material into $50 \mathrm{~L}$ of sifted sediment. Thus we obtained sediment with a mean \pm standard deviation of $4.50 \pm 1.13 \%$ low concentration organic matter and $9.4 \pm 1.17 \%$ high concentration. All experimental trials sediment were checked to organic matter quantification as described in item 2.2 .

Sediment grain size characterization was performed according to Suguio (1973). Sediment was composed of: $0.51 \%$ very coarse sand, $3.67 \%$ coarse sand, $19.87 \%$ medium sand, $28.89 \%$ fine sand, $7.31 \%$ very fine sand and $39.72 \%$ mud.

To evaluate the preference of crabs based on different organic content, we built microcosms (glass containers: $40 \times 10 \times 20 \mathrm{~cm}$ ) divided by a glass wall $(10 \mathrm{~cm}$ high $)$ into two compartments $(20 \times 10 \times 20 \mathrm{~cm})$ filled with a sediment column of $10 \mathrm{~cm}$. Microcosm area was based on the maximum density of $L$. uruguayensis observed in the Praia Grande estuary (see results, section 3.1), so that each compartment was sufficient for enclosing the territory of an individual crab (around $\left.13 \mathrm{~cm}^{2}\right)$. Depth of the sediment column $(10 \mathrm{~cm})$ was 
established in accordance with the maximum burrow depth for this species (Machado et al., 2013). We used one crab per microcosm to avoid intra-specific competition for territory as an interference factor. Microcosm walls were covered with opaque black plastic to avoid visual interference between animals. To avoid side bias as an interference factor, half of the animals were released on the left side and the other half were released on the right side for each treatment.

Crabs were kept on a light regime consisting of $12 \mathrm{~h}$ of light and $12 \mathrm{~h}$ of darkness, and at an average temperature of $28.99^{\circ} \mathrm{C}(\mathrm{SD} \pm 0.54)$. Crabs remained in the microcosms for $120 \mathrm{~h}$ based on preliminary observations wherein we evaluated the time necessary for the majority of active animals to be on the sediment surface. After this period each crab was observed for $10 \mathrm{~min}$ and the number of scoops was recorded. At the end of the observation, the number of pellets and burrows per compartment were recorded.

We compared the proportion of scoops, pellets and burrows dug out of one compartment (indicated by a subscript $t$ in each treatment, Fig. 2) relative to both compartments of each sediment type with and without choice (see Olabarria et al., 2002). Thus, preference of $L$. uruguayensis for sediment with high organic content could be indicated by a greater proportion of scoops or burrows dug into this type of sediment, compared to what would be expected by chance if no choice was expressed. The odds of crabs scooping sediment and building burrows in each microcosm compartment was estimated from treatments where there was no choice. Crab choice for sediments with high organic content was assumed when the following hypothesis was accepted:

$\mathrm{H} 1: \frac{n_{H_{t} 1}}{N_{1}}>\frac{n_{H_{t} 2}}{N_{2}}, \frac{n_{L_{t} 3}}{N_{3}}>\frac{n_{L_{t} 4}}{N_{4}}$

In this equation, $n_{H_{t} i}$ or $n_{L_{t} i}$ is the number of scoops, pellets or burrows observed in a single microcosm compartment (identified by a subscript $t$ ) referring to the amount of organic matter content in that treatment (High: $H$ or Low: $L$ organic content); $N$ is the total number of scoops or burrows observed in both compartments; and $i=1,2,3$ and 4 indicates the treatment. Choice treatments were 1 and 4 , and the ones without choice were 2 and 3 (Fig. 2).

If crabs chose sediment with high organic content, the proportion of scoops, pellets or burrows dug in compartment $\mathrm{H}_{\mathrm{t}}$ in treatment 1 must have been greater than that observed in $\mathrm{H}_{\mathrm{t}}{ }^{2}$ and $\mathrm{L}_{\mathrm{t}}{ }^{3}$ where there was no choice and the same proportion was expected. In treatment 4 , crabs would tend to feed and build their burrows in the high organic matter compartment, decreasing use of $\mathrm{L}_{t}{ }^{4}$. Therefore, it was hypothesized that the proportion of scoops and burrows in $H_{t}^{1}$ would be larger than in $H_{t}^{2}$, $H_{t}^{3}$ and the last ones greater than in $H_{t}^{4}$.

\subsection{Statistical analyses}

Our goal was to test whether variation of abundance and size of fiddler crabs is associated with variation of organic matter in their habitat. Since males and females of some species of fiddler crabs may occupy different patches of the intertidal zone (Christy, 1983; Croll and McClintock, 2000), we used a simple regression to test whether the sex ratio of $L$. thayeri or $L$. uruguayensis changes according to abundance of crabs per quadrat. Territorial competition (Christy, 1983; Croll and McClintock, 2000) or habitat selection between adults and juveniles (Ens et al., 1993) could also be a confounding effect in our analysis and thus we used a simple regression to test whether body size variation of both species were associated with variation of their respective abundance. We did not observe any relationship between variations of abundance and sex ratio or crab size per quadrat (see supplementary material). Thus, the relationship between total abundance and sediment organic matter variation was tested independently of sex and the relationship between crab size and organic matter was tested independently of their abundance.

A general linear model (GLM) was used to compare the relationship of crab size or abundance against organic matter between estuaries. The
Table 1

Sediment organic matter and population characteristics of Leptuca thayeri and $L$. uruguayensis from both Praia Grande and Peruíbe estuaries. Data show maximum, minimum and mean organic matter, fiddler crab abundance and carapace width.

\begin{tabular}{|c|c|c|c|c|c|c|c|c|}
\hline & \multicolumn{4}{|c|}{ Abundance } & \multicolumn{4}{|c|}{ Carapace width } \\
\hline & $d f$ & MS & $\mathrm{F}$ & $\mathrm{p}$ & $d f$ & MS & $\mathrm{F}$ & $\mathrm{p}$ \\
\hline \multicolumn{9}{|c|}{ Leptuca thayeri } \\
\hline Site & 1 & 0.941 & 19.623 & $<0.001$ & 1 & 465.52 & 24.367 & $<0.001$ \\
\hline $\begin{array}{c}\text { Organic } \\
\text { matt- } \\
\text { er }\end{array}$ & 1 & 1.229 & 25.628 & $<0.001$ & 1 & 8.46 & 0.443 & 0.506 \\
\hline Error & 291 & 0.047 & & & 291 & 19.10 & & \\
\hline \multicolumn{9}{|c|}{ Leptuca uruguayensis } \\
\hline Site & 1 & 0.775 & 6.5721 & 0.011 & 1 & 46.573 & 23.991 & $<0.001$ \\
\hline $\begin{array}{c}\text { Organic } \\
\text { matt- } \\
\text { er }\end{array}$ & 1 & 6.501 & 55.1151 & $<0.001$ & 1 & 20.833 & 10.732 & 0.0012 \\
\hline Error & 226 & 0.117 & & & 226 & 1.941 & & \\
\hline
\end{tabular}

predictor was represented by the different estuary sites and the percentage of organic matter represented the continuous variable. Standardized residuals were normally distributed and the scatter-plot of predicted values against residuals had a shotgun pattern. Abundance data were $\log (\mathrm{x}+1)$ transformed to attend the premise of normality. Simple linear regressions were used to explore any relationship among response variables and organic content.

The laboratory experiment hypotheses on crab choice were evaluated using a one-way analysis of variance (ANOVA). The proportional number of scoops, pellets and burrows dug by adult or juvenile crabs were arcsine transformed with the purpose of attending the ANOVA's premise of normality and homogeneity. We considered $95 \%$ as the significance level in all analyses.

\section{Results}

\subsection{Field experiment}

For Leptuca thayeri populations, the quantity of sediment organic matter in the Praia Grande was higher than in the Peruíbe estuary (Table 1). Abundance of $L$. thayeri also differed between estuaries (Table 2), with more crabs in Praia Grande than Peruíbe (Table 1). Abundance of tested crabs considering the effect of organic matter gradient differed between Praia Grande and Peruíbe (Table 2). Abundance of $L$. thayeri showed a small relationship with organic matter variation in Praia Grande but not in Peruíbe (Fig. 3 A).

For Leptuca uruguayensis, higher values of organic matter and crab abundance were observed in Peruíbe (Tables 1 and 2). Nevertheless, results from the regression test showed a weak relationship between abundance of $L$. uruguayensis and organic matter in Praia Grande (Table 2 and Fig. 3B).

Leptuca thayeri carapace mean size differed between estuaries, where they were larger in Peruíbe than in Praia Grande (Tables 1 and 2). No relationship was observed between $L$. thayeri size and organic matter variation (Table 2, Fig. 3, B). On the other hand L. uruguayensis carapace was larger in Praia Grande than in Peruíbe (Tables 1 and 2). Size variation of $L$. uruguayensis considering organic matter effect differed between estuaries (Table 2). In Peruíbe a weak relationship between L. uruguayensis size and organic matter was observed, but not in Praia Grande (Fig. 3).

\subsection{Laboratory experiment}

Leptuca uruguayensis showed no preference for feeding areas based on sediment organic matter content (Fig. 4). The proportion of scoops 
Table 2

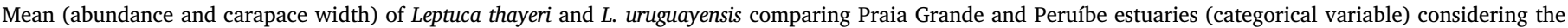
effect of organic matter (continuous variable). Level of significance adopted: $p<0.05$ (GLMs).

\begin{tabular}{|c|c|c|c|c|c|c|c|c|c|}
\hline & \multicolumn{3}{|c|}{ Organic matter of sediment (\%) } & \multicolumn{3}{|c|}{ Abundance } & \multicolumn{3}{|c|}{ Carapace width (mm) } \\
\hline & $\min$ & $\max$ & mean & $\min$ & $\max$ & mean & $\min$ & $\max$ & mean \\
\hline Praia Grande & 0.06 & 22.63 & 9.01 & 1 & 17 & 4.23 & 3.3 & 22.8 & 9.88 \\
\hline Peruíbe & 1.66 & 11.9 & 5.1 & 1 & 12 & 3.25 & 3.6 & 24.32 & 12.7 \\
\hline Praia Grande & 0.01 & 9.55 & 1.82 & 1 & 28 & 7.39 & 0.92 & 10.72 & 6.46 \\
\hline Peruíbe & 0.48 & 6.18 & 2.27 & 2 & 87 & 19 & 3.4 & 7.6 & 5.42 \\
\hline
\end{tabular}

was essentially the same between treatments for large crabs (one-way ANOVA: $\mathrm{F}_{3,36}=1.72, \mathrm{MS}=0.6728, \mathrm{p}=0.1787$ ) and small crabs $\left(\mathrm{F}_{3,36}=0.70, \mathrm{MS}=0.3410, \mathrm{p}<0.5568\right)$. Similarly, the number of surface pellets did not differ between treatment trials for adults $\left(\mathrm{F}_{3,36}=1.02, \mathrm{MS}=0.4177, \mathrm{p}=0.3931\right)$ and juveniles $\left(\mathrm{F}_{3,36}=1.17\right.$, $\mathrm{MS}=0.4728, \mathrm{p}=0.3334$ ). Moreover, L. uruguayensis did not show burrowing location preference. Proportion of burrows did not differ between treatments for either big (one-way ANOVA: $F_{3,36}=1.02$, MS $=0.3425, \quad \mathrm{p}=0.3927$ ) or small crabs (one-way ANOVA: $\mathrm{F}_{3,36}=0.40, \mathrm{MS}=0.1004, \mathrm{p}<0.7475$ ).

\section{Leptuca thayeri}
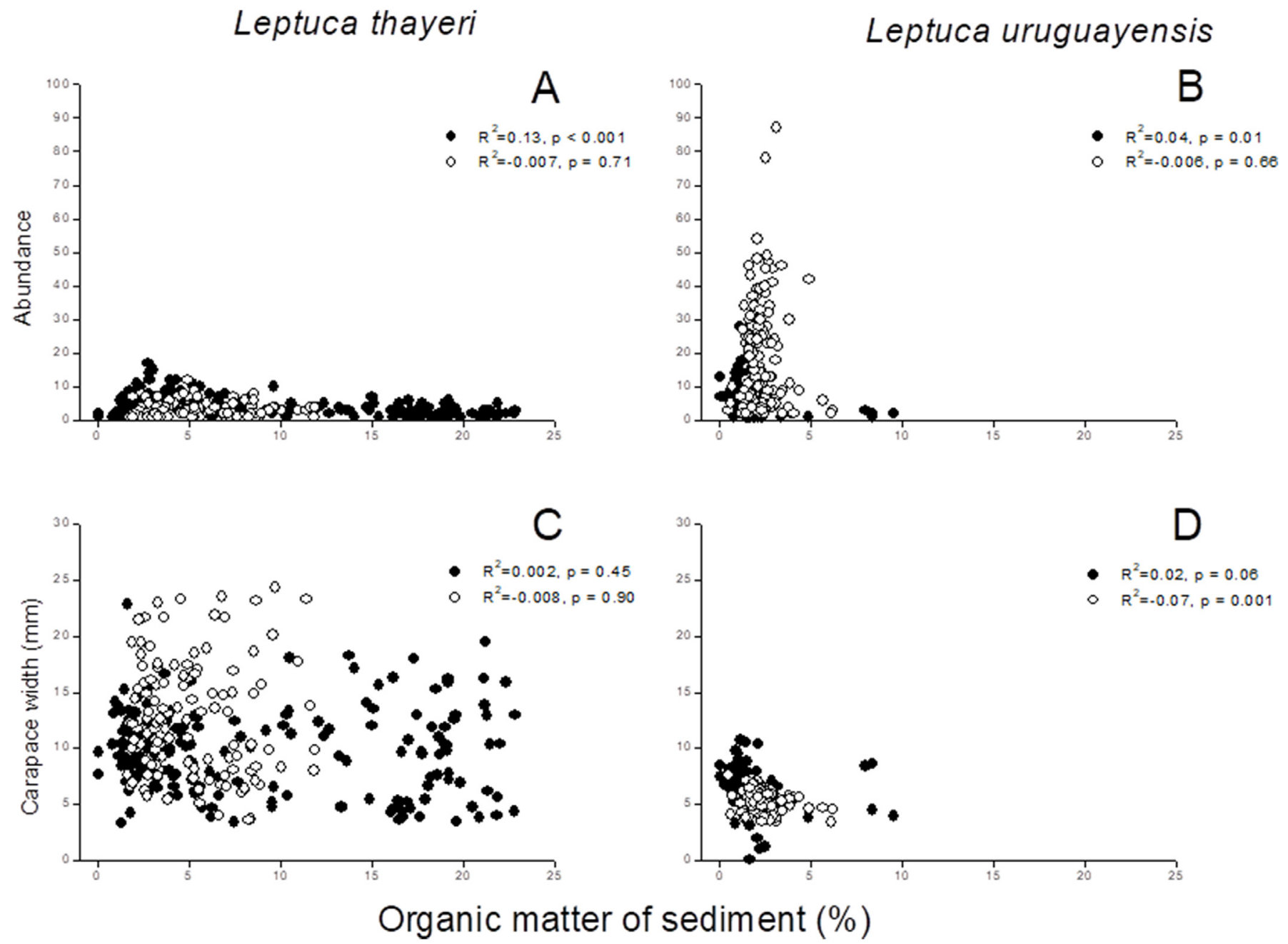

\section{Discussion}

Herein, we demonstrated that abundance and size of Leptuca thayeri and Leptuca uruguayensis are not influenced by the amount of organic matter in the mangrove sediment. In addition, we showed that $L$. uruguayensis adults and juveniles do not choose where to feed or dig their burrows due to organic matter concentration. Thus, our results suggest that the water-land gradient decrease of organic matter does not affect the intra-specific distribution of fiddler crabs in mangrove forests. organic matter as the main responsible for the differential distribution
Despite there being substantial literature suggesting or describing

Leptuca uruguayensis

Fig. 3. Field experiment results. The relationship between fiddler crab abundance and carapace width to sediment organic matter variation. A and $C$ show the data for Leptuca thayeri abundance and carapace width, respectively. B and D show the data for L. uruguayensis abundance and carapace width, respectively. The $\mathrm{x}$-axis represents average organic matter per quadrat sampled along transects. The y-axis represents mean response variables (abundance or carapace width) per quadrat sampled. Black color represents the Praia Grande estuary and white color represents the Peruíbe estuary. $\mathrm{R}^{2}$ and $\mathrm{p}$ from regression tests are shown at the top right of each graph. 


\section{Juveniles}
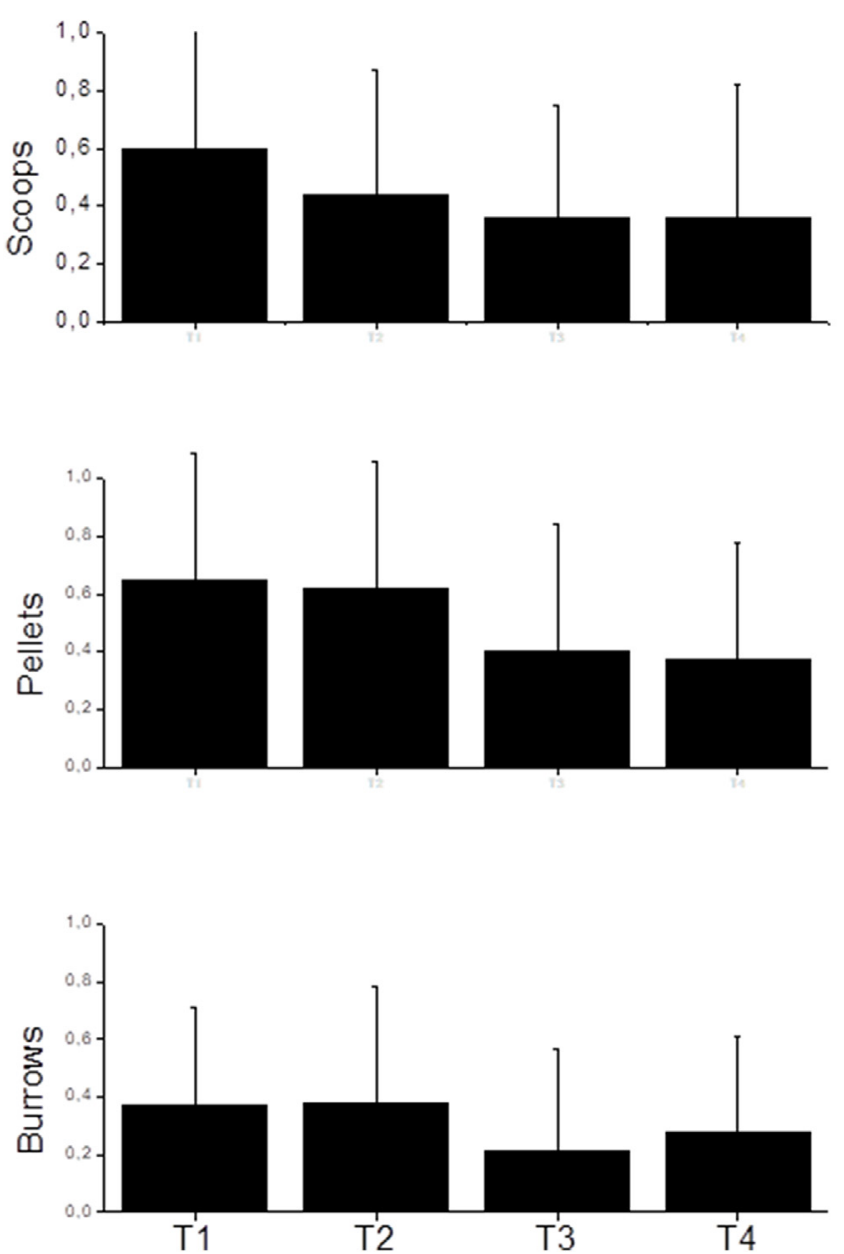
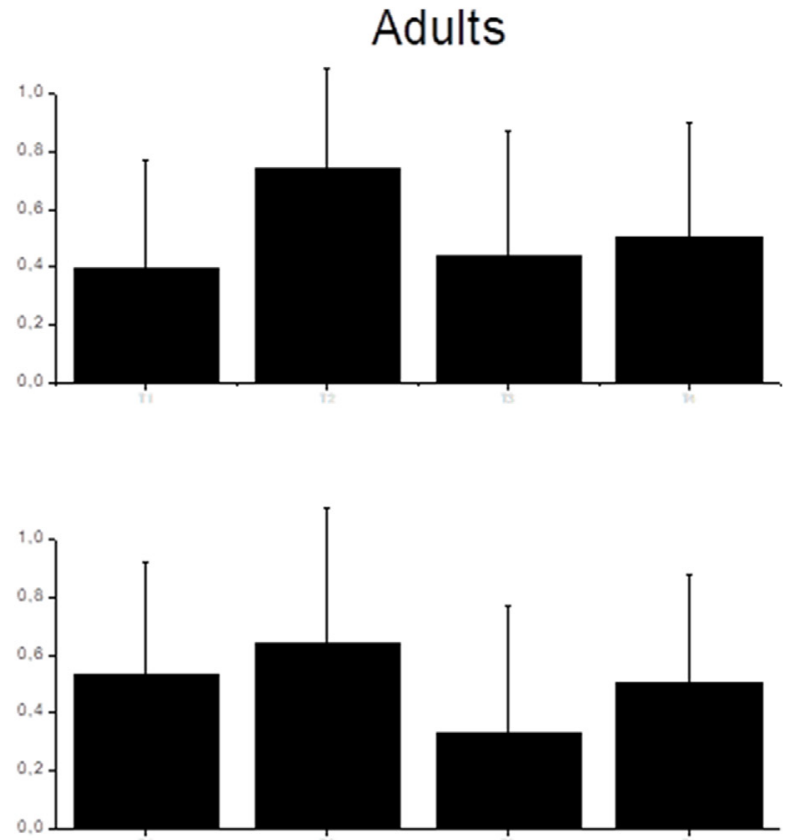

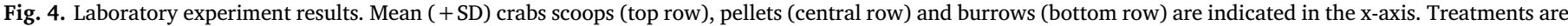

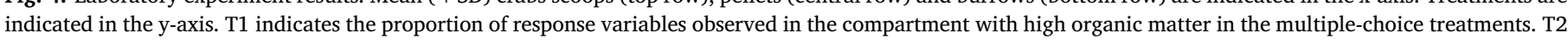

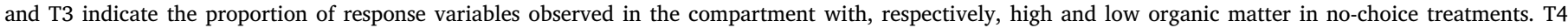
indicates the proportions observed in the compartment with low organic matter in the multiple-choice treatment.

of fiddler crabs (Crane, 1975; Reinsel and Rittschof, 1995; Costa and Negreiros-Fransozo, 2001; Ribeiro et al., 2005; Bezerra et al., 2006; Thurman et al., 2013; Mokhtari et al., 2015), our study showed an opposite pattern to what has been previously described. In our field experiment, abundance and size of $L$. thayeri and L. uruguayensis showed a weak relation with organic matter. Furthermore, the intra-specific distribution of both species in the two studied locations was not dependent of organic matter concentration. In the same sense, in the laboratory, $L$. uruguayensis did not show preference behavior for sediment organic matter concentration, since we did not observe a greater proportion of digging or feeding behavior on sediment with high organic matter in the multiple-choice treatment. Disparity between the literature and our study indicates that quantity of organic matter may not be the main factor explaining fiddler crab distribution within a single patch. Others biotic or abiotic factors as intraspecific competition, predation, grain size or even organic matter quality could play a more important role in fiddler crab distribution, as proposed previously (Boto and Iribarne, 2000; Bouillon et al., 2002; Meziane et al., 2002; Kon et al., 2007; Checon and Costa, 2017).

In mangrove forests, the main source of sediment organic matter is leaf litter and other tree fragments (Bouillon et al., 2003; Kon et al., 2007), validating their use as the main source of organic matter in our laboratorial experiments. Tree debris can be the primary carbon source for some consumers in mangrove forests (Kon et al., 2007), as many infaunal or epifaunal macroinvertebrates feed on tree fragments in the sediment (Guest et al., 2006; Kon et al., 2007). Nevertheless, the importance of tree fragment organic matter for primary consumers in mangrove forests has been overestimated (Bouillon et al., 2002, 2003; Kon et al., 2007; Lee et al., 2014). Tree debris presents high levels of low-digestible substances such as cellulose and tannins (Linton and Greenaway, 2007). Therefore, some selective consumers that inhabit the mangrove sediment may feed from other, easier to digest carbon sources, such as microphytobenthos or phytoplankton deposited on the sediment during high tides (Bouillon et al., 2002; Kon et al., 2007).

In the present study we did not evaluate whether $L$. thayeri or $L$. uruguayensis ingest the detritus of the trees. Nevertheless, the assumption that fiddler crabs ingest other sources of organic matter might be reinforced by the fact that fiddler crabs have, in the second maxilliped, specialized setae that they use to separate organic from nonorganic fractions of sediment. Setae morphology varies among fiddler crab species and these are used for food selection (Costa and NegreirosFransozo, 2001; Colpo and Negreiros-Fransozo, 2013). They are able to sort diatoms or bacteria from the sediment by a mechanism of water resuspension into the buccal chamber (Miller, 1961; France, 1998). Meziane et al. (2002) suggested that during sorting fiddler crabs may ingest mangrove debris but these are not digested. Moreover, Ribeiro et al. (2005) showed a positive relationship between abundance of $L$. uruguayensis and sediment organic matter in Argentina, studying a 
population inhabiting a non-vegetated sandy bank. The mean source of carbon in non-vegetated areas is the microphytobenthos (Miller et al., 1996; Kon et al., 2007; Ribeiro and Iribarne, 2011). In this sense, organic matter derived from tree debris would not be the main food source for fiddler crabs, a possible explanation why its quantity does not affect the intra-specific distribution of $L$. thayeri and $L$. uruguayensis. Other carbon sources could be more important in explaining the distribution of selective consumers and the identification of such sources is required at a species-specific level. Future studies on preference for a carbon source of certain quality could provide a better understanding of the distribution of fiddler crabs and whether their boundaries are limited by food or other biotic or abiotic factors.

\section{Conclusion}

Our work demonstrates that the quantity of organic matter does not explain fiddler crab intraspecific distribution in mangrove forests. Therefore, the variation of abundance or size within a single patch of fiddler crabs is not caused by the decrease of organic matter in a waterland gradient. More studies should evaluate if the quality of organic matter or other abiotic and biotic factors might be more important in this context.

\section{Acknowledgements}

We thank Drs. Skov M., Cannicci S. and Quadros, A.F. for their valuable suggestions for the improvement of this work; Oliveira R., Miyai C., Carvalho R., Jimenez P., Pardo J., Natálio L.F., Arvigo A., Citadin M., Cossignani E., Niero T., Ogata B., Fortuna M., Wendeborn M., Vianna B., Fogo B., and Cordeiro L. for their help in field and laboratory work; Machado G., for statistical analyses suggestions; and Dr. Fornari M. for her suggestion on sediment particle size analysis. This work was financially supported by grant \#2014/00456-7, São Paulo Research Foundation (FAPESP) (De Grande, FR) and by the Brazilian Research Council (CNPq \# 303400/2012-9) (Costa, TM). This research had permission from the system of authorization and information on biodiversity (Sisbio), Brazilian Ministry of the Environment (number: 47478-1).

\section{Appendix A. Supplementary data}

Supplementary data related to this article can be found at https:// doi.org/10.1016/j.ecss.2018.07.005.

\section{References}

Alvares, C.A., Stape, J.L., Sentelhas, P.C., Gonçalves, J.L., de, M., 2014. Köppen's climate classification map for Brazil. Meteorol. Z. 22, 711-728.

Bezerra, L.E.A., Dias, C.B., Santana, G.X., Matthews-cascon, H., 2006. Spatial distribution of fiddler crabs (genus Uca) in a tropical mangrove of northeast Brazil. Sci. Mar. 70, 759-766.

Botto, F., Iribarne, O., 2000. Contrasting effects of two burrowing crabs (Chasmagnathus granulatus and Uca uruguayensis) on sediment composition and transporting in estuarine environments. Estuar. Coast Shelf Sci. 51, 141-151.

Bouillon, S., Koedam, N., Raman, A.V., Dehairs, F., 2002. Primary producers sustaining macro-invertebrate communities in intertidal mangrove forests. Oecologia 130, 441-448.

Bouillon, S., Dahdouh-Guebas, F., Rao, A.V.V.S., Koedam, N., Dehairs, F., 2003. Sources of organic carbon in mangrove sediments: variability and possible ecological implications. Hydrobiologia 495, 33-39.

Booksmythe, I., Jennions, M.D., Backwell, P.R., 2010. Interspecific assistance: fiddler crabs help heterospecific neighbours in territory defence. Biol. Lett. 6, 748-750.

Cammen, L.M., Seneca, E.D., Stroud, L.M., 1980. Energy flow through the fiddler crabs Uca pugnax and U. minax and the marsh periwinkle Littorina irrorata in a North Carolina salt marsh. Am. Midl. Nat. 103, 238-250.

Cannicci, S., Fusi, M., Cimó, F., Dahdouh-Guebas, F., Fratini, S., 2018. Interference competition as a key determinant for spatial distribution of mangrove crabs. BMC Ecol. 18, 01-12.

Checon, H.H., Costa, T.M., 2017. Fiddler crab (Crustacea: Ocypodidae) distribution and the relationship between habitat occupancy and mouth appendages. Mar. Biol. Res. $13,618-629$.
Christy, J.H., 1983. Female choice in the resource-defense mating system of the sand fiddler crab, Uca pugilator. Behav. Ecol. Sociobiol. 12, 169-180.

Colpo, K.D., Negreiros-Fransozo, M.L., 2013. Morphological diversity of setae on the second maxilliped of fiddler crabs (Decapoda: Ocypodidae) from the southwestern Atlantic coast. Invertebr. Biol. 132, 38-45.

Costa, T.M., Negreiros-Fransozo, M.L., 2001. Morphological adaptation of second maxilliped in semiterretrial of genus Uca Leach, 1814 (Decapoda, Ocypodidae) from a subtropical Brazilian mangrove. Nauplius 9, 123-131.

Costa, T.M., Negreiros-Fransozo, M.L., 2003. Population biology of Uca thayeri Rathbun, 1900 (Brachyura, Ocypodidae) in a subtropical South American Mangrove area: results from transect and catch-per-unit-effort techniques. Crustaceana 75 (10), 1201-1218.

Crane, J., 1975. Fiddler Crabs of the World Ocypodidae: Genus Uca, first ed. Princeton University Press, New York.

Croll, G.A., McClintock, J.B., 2000. An evaluation of lekking behavior in the fiddler crab Uca spp. J. Exp. Mar. Biol. Ecol. 254, 109-121.

Daleo, P., Ribeiro, P., Iribarne, O., 2003. The SW Atlantic burrowing crab Chasmagnathus granulatus Dana affects the distribution and survival of the fiddler crab Uca uruguayensis Nobili. J. Exp. Mar. Biol. Ecol. 291, 255-267.

Ens, B.J., Klaassen, N., Zwarts, L., 1993. Flocking and feeding in the fiddler crab (Uce tangeri): prey availability as risk-taking behavior. Neth. J. Sea Res. 31, 477-494.

Epifanio, C.E., Little, K.T., Rowe, P.M., 1988. Dispersal and recruitment of fiddler crab larvae in the Delaware River estuary. Mar. Ecol. Prog. Ser. 43, 181-188.

France, R., 1998. Estimating the assimilation of mangrove detritus by fiddler crabs in Laguna Joyuda, Puerto Rico using dual stable isotopes. J. Trop. Ecol. 14, 413-425.

Genoni, G.P., 1985. Food limitation in salt marsh fiddler crabs Uca rapax (Smith) (Decapoda: Ocypodidae). J. Exp. Mar. Biol. Ecol. 87, 97-110.

Guest, M.A., Connolly, R.M., Lee, S.Y., Loneragan, N.R., Breitfuss, M.J., 2006. Mechanism for the small-scale movement of carbon among estuarine habitats: organic matter transfer not crab movement. Oecologia 148, 88-96.

Hirose, G., Fransozo, V., Tropea, C., López- Greco, L.S., Negreiros-Fransozo, M.L., 2012. Comparison of body size, relative growth and size at onset sexual maturity of Uca uruguayensis (Crustacea: Decapoda: Ocypodidae) from different latitudes in the south western Atlantic. J. Mar. Biol. Assoc. U. K. 93, 1-8.

Huettel, A., Ziebis, W., Forster, S., 1996. Flow-induced uptake of particulate matter in permeable sediments. Limnol. Oceanogr. 41, 309-322.

Icely, J.D., Jones, D.A., 1978. Factors affecting the distribution of the genus Uca (Crustacea: Ocypodidae) on an east African shore. Estuar. Coast Mar. Sci. 6, 315-325.

Johnson, P.T.J., 2003. Biased sex ratios in fiddler crabs: a review and evaluation of the influence of sampling method, size class, and sex-specific mortality. Crustaceana 76 $559-580$.

Koch, V., Wolff, M., Diele, K., 2005. Comparative population dynamics of four fiddler crabs (Ocypodidae, genus Uca) from a North Brazilian mangrove ecosystem. Mar. Ecol.: Prog. Ser. 291, 177-188.

Koga, T., Backwell, P.R.Y., Christy, J.H., Murai, M., Kasuya, E., 2001. Male-biased predation of fiddler crab. Anim. Behav. 62, 201-207.

Koga, T., Backwell, P.R.Y., Jennions, M.D., Christy, J.H., 2015. Elevated predation risk changes mating behavior and courtship in fiddler crabs. Proc. Roy. Soc. Lond. B. 265 1395-1390.

Kon, K., Kurokura, H., Hayashizaki, K., 2007. Role of microhabitats in food webs of benthic communities in a mangrove forest. Mar. Ecol.: Prog. Ser. 340, 55-62.

Kristensen, E., 2008. Mangrove crabs as ecosystem engineers; with emphasis on sediment processes. J. Sea Res. 59, 30-43.

Krumme, U., Keuthen, H., Saint-Paul, U., Villwock, W., 2007. Contribution to the feeding ecology of the banded puffer fish Colomesus psittacus (Tetraodontidae) in north Brazilian mangrove creeks. Braz. J. Biol. 67, 383-392.

Lallier-verges, E., Perrussel, B., Disnar, R., Baltzer, F., 1998. Relationships between environmental conditions and the digenetic evolution of organic matter derived from higher plants in a modern mangrove swamp system (Guadeloupe, French West Indies). Org. Geochem. 29, 1663-1686.

Lee, S.Y., Primavera, J.H., Dahdouh-guebas, F., Mckee, K., Bosire, J.O., Cannicci, S., Diele, K., Fromard, F., Koedam, N., Marchand, C., Mendelssohn, I., 2014. Ecological role and services of tropical mangrove ecosystems : a reassessment. Global Ecol. Biogeogr. 23, 726-743.

Linton, S.M., Greenaway, P., 2007. A review of feeding and nutrition of herbivorous land crabs: adaptations to low quality plant diets. J. Comp. Physiol. B 177, 269-286.

Luczak, C., Janquin, M., Kupka, A., 1997. Simple standard procedure for the routine determination of organic matter in marine sediment. Hydrobiologia 345, 87-94.

Machado, G.B.O., Gusmão-Junior, J.B.L., Costa, T.M., 2013. Burrow morphology of Uca uruguayensis and Uca leptodactylus (Decapoda: Ocypodidae) from a subtropical mangrove forest in the western Atlantic. Integr. Zool. 8, 307-314.

Macintosh, D.J., Ashton, E.C., Havanon, S., 2002. Mangrove rehabilitation and intertidal biodiversity: a study in Ranong Mangrove Ecosystem. Thailand. Estuar. Coast. Shelf S 33, 331-345.

Martins, S.B., Masunari, S., 2013. Relative growth in the fiddler crab Uca uruguayensis Nobili, 1901 (Brachyura, Ocypodidae) from Garças river mangrove, Guaratuba Bay, southern Brazil. Nauplius 21, 35-41.

Masunari, S., 2006. Distribuição e abundância dos caranguejos Uca Leach (Crustacea, Decapoda, Ocypodidae) na Baía de Guaratuba, Paraná. Brasil. Rev. Bras. Zool 23, 901-914.

Meziane, T., Sanabe, M.C., Tsuchiya, M., 2002. Role of fiddler crabs of a subtropical intertidal flat on the fate of sedimentary fatty acids. J. Exp. Biol. 270, 191-201.

Michaels, R.E., Zieman, J.C., 2013. Fiddler crabs (Uca spp) burrows have a little effect surrounding sediment oxygen concentration. J. Exp. Mar. Biol. Ecol. 448, 104-113.

Miller, D.C., 1961. The feeding mechanisms of fiddler crabs with ecological considerations of feeding adaptations. Zool. Sci. Contrib. N. Y. Zool. Soc. 46, 8-100. 
Miller, D.C., Geider, R.J., MacIntyre, H.L., 1996. Microphytobenthos: the ecological role of the "secret garden" of unvegetated, shallow-water marine habitats. II. Role in sediment stability and shallow-water food webs. Estuaries 19, 202.

Mokhtari, M., Ghaffar, M.A., Usup, G., Cob, Z.C., 2015. Determination of key environmental factors responsible for distribution patterns of fiddler crabs in a tropical mangrove ecosystem. PLoS One 10, 01-17.

Natalio, L.F., Pardo, J.C.F., Machado, G.B.O., Fortuna, M.D., Gallo, D.G., Costa, T.M., 2017. Potential effect of fiddler crabs on organic matter distribution: a combined laboratory and field experimental approach. Estuar. Coast Shelf Sci. 184, 158-165.

Nobbs, M., Blamires, S.J., 2015. Spatiotemporal distribution and abundance of mangrove ecosystem engineers: burrowing crabs around canopy gaps. Ecosphere 6, 01-13.

Nobbs, M., 2003. Effects of vegetation differ among three species of fiddler crabs (Uca spp.). J. Exp. Mar. Biol. Ecol. 284, 41-50.

Olabarria, C., Underwood, A.J., Chapman, M.G., 2002. Appropriate experimental design to evaluate preferences for microhabitat: an example of preferences by species of microgastropods. Oecologia 132, 159-166.

Reinsel, K.A., Rittschof, D., 1995. Environmental regulation of foraging in the sand fiddler crab Uca pugilator (Bosc 1802). J. Exp. Mar. Biol. Ecol. 187, 269-287.

Ribeiro, P.D., Iribarne, O.O., 2011. Coupling between microphytobenthic biomass and fiddler crab feeding. J. Exp. Mar. Biol. Ecol. 407, 147-154.

Ribeiro, P.D., Iribarne, O.O., Daleo, P., 2005. The relative importance of substratum characteristics and recruitment in determining the spatial distribution of the fiddler crab Uca uruguayensis Nobili. J. Exp. Mar. Biol. Ecol. 314, 99-111.

Rulison, E.L., Luiselli, L., Burke, R.L., 2012. Relative impacts of habitat and geography on raccoon diets. Am. Midl. Nat. 168, 231-246.

Sanford, E., Holzman, S.B., Haney, R.A., Rand, D.M., Bertness, M.D., 2006. Larval tolerance, gene flow, and the northern geographic range limit of fiddler crabs. Ecology 87, 2882-2894.

Suguio, K., 1973. Introdução à sedimentologia, first ed. São Paulo University Press, São Paulo.

Teal, J.M., 1958. Distribution of fiddler crabs in Georgia salt marshes. Bull. Ecol. Soc. Am. 39, 186-193.

Teal, J.M., 1962. Energy flow in the salt marsh ecosystem of Georgia. Bull. Ecol. Soc. Am. 43, 614-624.

Thurman, C.L., Faria, S.C., McNamara, J.C., 2013. The distribution of fiddler crabs (Uca) along the coast of Brazil: implications for biogeography of the western Atlantic Ocean. Mar. Biodivers. Rec 6, 01-21.

Underwood, A.J., 1997. Experiments in Ecology, first ed. Cambridge University Press, Cambridge, pp. 524.

Underwood, A.J., Chapman, M.G., Crowe, T.P., 2004. Identifying and understanding ecological preferences for habitat or prey. J. Exp. Mar. Biol. Ecol. 300, 161-187.

Weis, J.S., Weis, P., 2004. Behavior of four species of fiddler crabs, genus Uca, in southeast Sulawesi, Indonesia. Hydrobiologia 523, 47-58.

Weissburg, M., 1992. Functional analysis of fiddler crab: sex-specific mechanics and constraints in Uca pugnax (Smith). J. Exp. Mar. Biol. Ecol. 156, 105-124.

Yang, S.L., Li, H., Ysebaert, T., Bouma, T.J., Zhang, W.X., Wang, Y.Y., Li, P., Li, M., Ding, P.X., 2008. Spatial and temporal variation in sediment grain size in coastal wetlands, Yangtze Delta: on the role of physical and biotic controls. Estuar. Coast Shelf Sci. 77 657-671.

Zar, J.H., 2010. Biostatistical Analysis Fifth Ed. Prentice Hall, Upper Saddle River, New Jersey. 